 \\ $112^{4}$ \\ PHASE 2 OF THE ARRAY AUTOMATED ASSEMBLY TASK FOR THE \\ LOW COST SILICON SOLAR ARRAY PROJECT
}

Seventh Quarterly Report

By

Raymond C. Petersen

July 1980

Work Performed Under Contract No. NAS-7-100-954854

Solarex Corporation

Rockville, Maryland
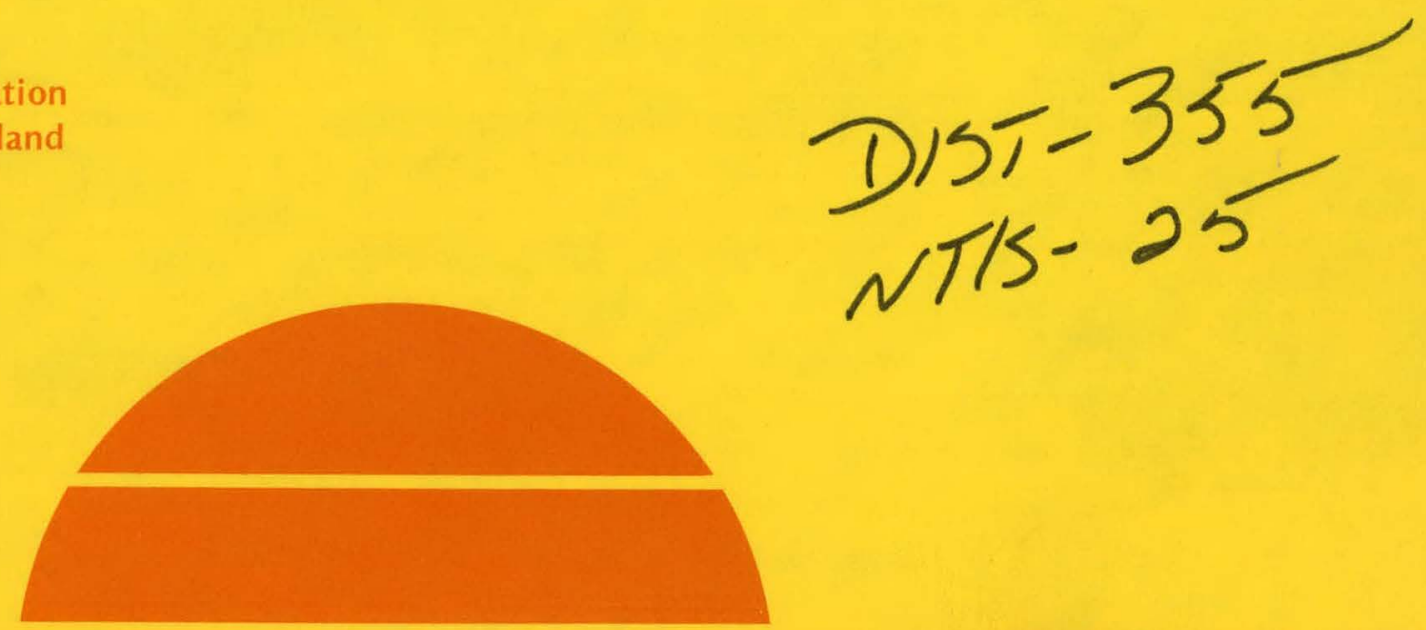

\section{U.S. Department of Energy}

RIII

Solar Energy 


\section{DISCLAIMER}

This report was prepared as an account of work sponsored by an agency of the United States Government. Neither the United States Government nor any agency Thereof, nor any of their employees, makes any warranty, express or implied, or assumes any legal liability or responsibility for the accuracy, completeness, or usefulness of any information, apparatus, product, or process disclosed, or represents that its use would not infringe privately owned rights. Reference herein to any specific commercial product, process, or service by trade name, trademark, manufacturer, or otherwise does not necessarily constitute or imply its endorsement, recommendation, or favoring by the United States Government or any agency thereof. The views and opinions of authors expressed herein do not necessarily state or reflect those of the United States Government or any agency thereof. 


\section{DISCLAIMER}

Portions of this document may be illegible in electronic image products. Images are produced from the best available original document. 


\section{DISCLAIMER}

"This book was prepared as an account of work sponsored by an agency of the United States Government. Neither the United States Government nor any agency thereof, nor any of their employees, makes any warranty, express or implied, or assumes any legal liability or responsibility for the accuracy, completeness, or usefulness of any information, apparatus, product, or process disclosed, or represents that its use would not infringe privately owned rights. Reference herein to any specific commercial product, process, or service by trade name, trademark, manufacturer, or otherwise, does not necessarily constitute or imply its endorsement, recommendation, or favoring by the United States Government or any agency thereof. The views and opinions of authors expressed herein do not necessarily state or reflect those of the United States Government or any agency thereof."

This report has been reproduced directly from the best available copy.

Available from the National Technical Information Service, U. S. Department of Commerce, Springfield, Virginia 22161.

Price: Paper Copy $\$ 6.00$

Microfiche $\$ 3.50$ 


\title{
PHASE 2 OF THE ARRAY AUTOMATED ASSEMBLY TASK \\ FOR THE LOW COST SILICON SOLAR ARRAY PROJECT
}

\author{
SEVENTH QUARTERLY REPORT
}

JULY, 1980

\author{
RAYMOND C. PETERSEN \\ SOLAREX CORPORATION \\ 1335 Piccard Drive. \\ Rockville, MD 20850
}

"The JPL low-cost Silicon Solar Array Project is sponsored by the U.S. Department of Energy and forms part of the solar Photovoltaic Conversion Program to initiate a major effort toward the development of low-cost solar arrays. This work was performed for the Jet Propulsion Laboratory, California Institute of Technology by agreement between NASA and DOE." 
THIS PAGE

\section{WAS INTENTIONALLY LEFT BLANK}


Work during this quarter emphasized the evaluation of the Motorola metallization process, the major experimental task of the program.

The Motorola process is a lengthy one, designed to assure reproducible metallization of solar cells, but we have found it difficult to reproduce relative to a single step electroless nickel plating.

We also conclude, on the basis of experiments performed to date, that the product of the Motorola process is virtually identical to the product of a simple electroless nickel plating process. 
TABLE OF CONTENTS

Page

1. Introduction 1

2. Motorola Process 2

2.1 Reliability and Reproducibility 2

3. Etching of Silicon by Plating Solutions 4

4. Tape Peel Test 6

5. Tab Pull Tests 7

6. Diodes , 10

7. Photovoltaic Cells 12

8. Back Surface Metallization 16

9. Conclusions 17

10. Recommendations 18

10.1 Nickel Metallization \& Thermal Stress 18

10.2 Electroless Nilkel-Copper-N1Ckel $\begin{array}{ll}\text { Metallizalion } & 19\end{array}$

11. Work Status 22

12. Work Plan 22

13. References . . 23

Appendix A - Motorola Specifications 24 
1. INTRODUCTION

Work during this quarter was concentrated on the final experimental task of the program extension, the evaluation of the Motorola plating process relative to simple electroless nickel plating. This task represents the major focus of the program.

The Motorola metallization process (1) has been considered by Motorola "to contain the maximum number of process steps required for assured metallization of n-on-p solar cells with $n+$ front surfaces and p+ back surfaces." Motorola has also cautioned, however, that the. "process sequence reported here may require minor modifications to account for different types of solar cell substrates and to account for the previous processing history of substrates prior to metallization."

The Motorola process is a complex and lengthy one, culminating in an electroless nickel plating step. It is our purpose to devise and to perform experiments which will reveal any advantages which the complex Motorola process might provide over a single step electroless nickel plating, and to provide an overall assessment of the utility of the process. 


\section{MOTOROLA PROCESS}

The Motorola process is a complex one; it utilizes the standard electroless nickel plating solution of Brenner and Riddell $(3,4)$, but it precedes the electroless nickel plating step with three steps of immersion palladium plating, one step of electroless palladium plating, two heat treatment steps and several cleaning and rinsing steps.

The Motorola process specification, as supplied by Motorola to JPI, is included herein as Appendix A:

The specification defines twenty-eight steps, exclusive of the solder dipping operation, and requires one hour and forty-nine minutes, not including any time for transfer, inspection, cooling and drying operations. This is an extremely lengthy process relative to a single step nickel plating process, and we have been most forcibly impressed by the cumbersome, time consuming nature of the process.

\subsection{Reliability and Reproducibility}

The major purpose of the complex processing prior to the nickel plating step is to assure repeatable and reliable metallization of the solar cells, by eliminating or minimizing any effects of prior processing of the silicon. 
We have run the Motorola process many times with variable results. Metallization sometimes lifts spontaneously from the silicon before the process has been completed, frequently during the electroless palladium plating step, and it sometimes works very well, giving an adherent, good looking plate. Thus, it appears to us that success of the Motorola process is at least as dependent upon prior history of the specimen as is the simple electroless nickel plating process.

In an effort to improve repeatability of the process, we have tested several preliminary specimen treatments, and have chosen to use a piranha etch ( 1 min in a mixture of 2 parts conc $\mathrm{H}_{2} \mathrm{SO}_{4}$ and $I$ part $30 \% \mathrm{H}_{2} \mathrm{O}_{2}$ ) followed by a deionized water rinse and spin drying, because it appears to aid in achieving reasonably reproducible results.

Our second general observation, then, is that the Motorola process is not the highly reproducible and reliable process it was intended to be, and this fact is recognized by Motorola in the caveat, quoted previously, that the "process .... may require minor modifications to account for different types of solar cell substrates and .... the previous processing history of substrates...." 


\section{ETCHING OF SILICON BY PLATING SOLUTIONS}

We reported previously (5) that the electroless nickel plating solution can dissolve silicon dioxide. We are also aware that the electroless nickel and palladium plating solutions can etch silicon if they are not plating metal, and that the immersion palladium plating solution also removes some silicon.

To detect any possible effects of etching, we measured sheet resistances and illuminated open circuit voltages of several cells prior to metallization, then plated them, removed the metallization, and measured these parameters again. Piranha etch removed all of the nickel and most of the palladium, but traces of palladium appeared to remain; treatment with aqua regia for 2 minutes removed all of the metal. Results of this experiment are shown in Table 1 .

\section{Table 1}

Electrical Parameters Before Plating and After Stripping of Metallization

Illuminated $V_{\text {oc }}(\mathrm{mV}) \quad$ Sheet Resistance (ohms $\square$ )

Before After Before After

$\begin{array}{rcccc}\text { Motorola } & & & \\ \text { Range } & 543-583 & 298-468 & 54-55 & 310-360 \\ \text { Mean } & 567 & 373 & 55 & 335 \\ \text { Ni Only } & & & & \\ \text { Range } & 536-591 & 467-547 & 54-55 & 57-67 \\ \text { Mean } & 555 & 509 & 55 & 61\end{array}$


Sheet resistances, originally 54-55 ohms per square, measured 57-67 ohms per square in the group plated with nickel only, but had increased to 310-360 ohms per square in the group plated using the Motorola process.

Illuminated open circuit voltages decreased in all cases, but the change was relatively small in the cells plated with nickel only and was large in the cells plated by the Motorola process.

We concluded that some silicon was etched in these plating processes, and that the Motorola process removes more silicon than does the simple electroless nickel plating process. Thus it appears that a deeper diffusion is required for the Motorola process. 
4. TAPE PEEL TEST

A group of 2" diameter round polished silicon wafers ( $C z$, p-type, 1-0-0, 0.2-5 ohm-cm) was given the piranha pre-treatment followed by phosphine diffusion, glass removal by dilute $\mathrm{HF}$, aluminum back alloy, and removal of excess aluminum by cold conc $\mathrm{HCl}$.

Half of the cells were plated using the Motorola process, and the other half were plated using only the electroless nickel plating step of the Motorola process. Adhesion of the metallization was tested by pressing adhesive tape to the metal and peeling it off.

The adhesion was quite good in all cases with only small amounts of metal lifting near edges or in very small isolated spots. We estimate 98-99: adherence to the specimens plated with nickel only and $99+8$ adherence to the specimens plated by the Motorola process.

We interpret these observations as indicating essentially identical behavior in the two groups. 


\section{TAB PULL TEST}

Another group of silicon wafers was prepared as before (piranha, diffusion, alloying, cleaning) and portions of the group were plated using a) the Motorola process, b) the electroless nickel plating step of the Motorola process, and c) the electroless nickel plating solution of the J.E. Halma Company. We have used the proprietary Halma solution extensively, and, while we do not know its composition, we believe it is similar to the Brenner solution used by Motorola.

A pattern of buses, about $1 \mathrm{~mm}$ wide, was formed on the cells and the cells were dipped in molten solder after plating. Tinned copper tabs, $1.75 \mathrm{~mm}$ wide, were soldered to the buses, and $90^{\circ}$ tab pull tests were conducted. Some of the specimens having nickel only were sintered for $1 \mathrm{~min}$ at $250^{\circ} \mathrm{C}$ prior to solder dipping. The Motorola process, of course, incorporates heat treatment steps.

Results of the tab pull tests are shown in Table 2 . The adhesion is clearly poorest in the group using the Motorola process, though not significantly different from the results obtained with the unsintered plates using nickel only. Sintering obviously produced a dramatic improvement. 
Table 2

Tab Pull Tests

Process

Motorola

Brenner Nickel

Halma Nickel

Brenner $\mathrm{Ni}$ (sintered)

Halma Ni (sintered)
Tab Pull Strength (g)

$$
\text { Range }
$$$$
0-184
$$$$
0-249
$$$$
0-289
$$

$150-737$

$113-601$
Mean (Std. Dev.)

67 (59)

$98(106)$

$111(107)$

$407(198)$

$319(161)$

We have previously observed that sintering can create a major improvement in adhesion in some cases where adhesion is not very good prior to sintering. We have also observed that excellent adhesion is sometimes obtained without sintering. With these facts in mind we repeated the experiment of Table 2, but using only the Motorola process and the Brenner electroless nickel plating solution. Results are shown in Table 3 .

Table 3

Tab Pull Tests

Process

Motorola

Brenner $\mathrm{Ni}$ (unsintered)
Tab Pull Strength (g)

$$
\text { Range }
$$

$62-400$

$57-451$
Mean (Std. Dev.)

$288(190)$

248 (137) 
It is evident that better adhesion was obtained this time in both cases, despite the fact that no conscious changes were made in the processing, and it is most significant that the Motorola process was affected in exactly the same way as was the simple electroless nickel plating process.

The Motorola process calls for five minutes of electroless nickel plating at $80^{\circ} \mathrm{C}$, and these are the conditions we used in all of these experiments. We have previously reported (5) obtaining best results when plating for six to ten minutes at $90^{\circ} \mathrm{C}$. Therefore, we believe that the relatively poor adhesion and great variability in the data of these experiments results from a nickel thickness which is somewhat less than ideal. 


\section{DIODES}

Diodes were fabricated using both the Motorola process and the electroless nickel plating step alone, and diode quality factors ( $\mathrm{f}$ factors) were determined from measurements of dark current as a function of bias voltage.

We know that these $\mathrm{n}$ factors (at the maximum power point) are near unity for our titanium/palladium/silver metallization but are usually closer to two for nickel/ solder metallization, so we thought that any signficant differences between the products of the complex Motorola process and simple electroless nickel plating might be evidenced by a significant difference in this factor.

In our first experiment, cffective diode $n$ factors at 0.45 volt were found to be greater than two in all cases, and there was considerable scatter in the data, especially great in the Motorola process diodes. Some of the diodes made with the Motorola process showed $n$ factors much qreater than two, and removal of the metallization followed by measurements of sheet resistivity showed that the diffused region had been substantially altered. Consequently, this experiment was repeated using a deeper diffusion. 
Reproducibility was much better in this second experiment, and results of the measurements are shown in Table 4. Dark reverse currents were subtracted from the dark forward currents in obtaining these $\mathrm{n}$ factors, and, in calculating average values, one diode was dropped from each group as being obviously shorted (forward and reverse currents nearly identical), and three diodes were eliminated (one from the Motorola process group and two from the nickel only group) because their $\mathrm{n}$ factors were more than three standard deviations higher than the means of their respective groups.

Table 4

Diode n Factors

Process

Motorola (21 diodes)

Nickel only (16 diodes) n Factor

2.29

2.21
Std. Dev.

$$
0.24
$$

0.26

Obviously these diode characteristics provide no distinction between the two metallization processes. 


\section{PHOTOVOLTAIC CELLS}

Attempts were made to fabricate solar cells using the Motorola process with a variety of masking techniques to form the front metalization pattern. Screen printed inks, evaporated coatings and photolith processes, with and without baking or sintering treatments, were tried with little success. One or more of the various cleaning and plating solutions attacked the masking material in every case.

We did not attempt to use the silicon nitride of Motorola because 1) Motorola did not specify the details of their masking process, perhaps regarding the process to be a proprietary one, and 2) we have more experience with other materials.

We did achieve success using a relatively thick mask of silicon dioxide. We have shown previously (5) that the electroless plating solutions dissolve silicon dioxide, but. the process is not a rapid one, and an oxide thickness of about 2,000 Angstroms appears to serve our purpose well.

In the first successful cell fabrication, round $\mathrm{Cz}$ wafers (2.94" diameter, p type) were used with phosphorus diffusion to form the $\mathrm{p}-\mathrm{n}$ junction and with alloyed aluminum backs. About 1,800 Angstroms of $\mathrm{SiO}_{2}$ was formed on the 
fronts of the cells (Silox process), and a masking pattern was produced by photolithography and a buffered HF etch. The photoresist was removed in acetone prior to plating.

The pattern chosen had relatively wide metallized areas with large separations, and metal covered about $15 \%$ of the front cell surface. This is not a pattern calculated to produce efficient cells, but it was considered to be a desirable one for the purpose of comparing the two different metal plating procedures without introducing unnecessary complications or uncertainties related to the mask.

Eleven cells were fabricated using the Motorola sequence and thirteen cells were made using just the electroless nickel plating step of the Motorola process: We felt that the 1,800 Angstroms of $\mathrm{SiO}_{2}$ might not be adequate to withstand all of the HF treatments of the Motorola process, so in this experiment we modified the process by reducing the HF treatments. We also felt that the HF treatments were probably not necessary, since $\mathrm{SiO}_{2}$ is removed by the plating solutions, and, in fact, we observed no plating difficulties.

Illuminated I-V measurements were made on these cells at AMl, and the data are shown in Table 5. The thick $\mathrm{SiO}_{2}$ coating was left in place for these measurements. 
Table 5

Electrical Characteristics of Cells

Process

Modified mean

Motorola (std.

( 8 cells) dev.)

Nickel

only

(12 cells)

mean
(std.
dev.)
Voc $\mathrm{mV}$

562.5

(13.1)

592.8

$(5.9)$
$I_{S C} \mathrm{~mA}$

1048

(75)

$$
\text { (75) }
$$

1058

(42)
$P_{m} \mathrm{~mW}$

363

(24)

370

(33)

There is little difference between the two groups in short circuit current and maximum power, the Motorola process group showing slightly lower values in each case, but cells made with the Motorola process show an open circuit voltage about $30 \mathrm{mV}$ below that of the cells using nickel only. We believe this difference results from greater penetration of the diffusion layer by the Motorola process.

Three cells in the Motorola process group and one cell in the nickel only group were not included in the measurements of Table 5, because their metallization showed some obvious weakness. We suggest that this results from the relatively thin nickel plate obtained by plating for five minutes at $80^{\circ} \mathrm{C}$, as discussed earlier in this report.

This experiment was repeated using a thicker $\mathrm{siO}_{2}$ mask (about 2,200 Angstroms) in combination with the complete 
Motorola process. The wafers in this case measured $7.50 \mathrm{~cm}$ in diameter and the $\mathrm{SiO}_{2}$ was removed and replaced with a tantalum oxide AR coating before measuring the electrical characteristics. Otherwise the processing was identical to that of the earlier experiment. Illuminated I-V data at AMO from these cells are shown in Table 6. Four obviously inferior Motorola process cells were not included in these averages, two having very low open circuit voltages, one having an exceptionally low short circuit current, and one showing abnormally low maximum power.

Table 6

Electrical Characteristics of Cells

$\begin{array}{lcccc}\text { Process } & & \mathrm{V}_{\mathrm{oc}} \mathrm{mV} & \mathrm{I}_{\mathrm{sc}} \mathrm{mA} & \mathrm{P}_{\mathrm{m}} \mathrm{mW} \\ \begin{array}{c}\text { Motorola } \\ \text { (13 cells) }\end{array} & \begin{array}{c}\text { Mean } \\ \text { (std. } \\ \text { dev.) }\end{array} & 543.7 & 1370 & 445 \\ & (6.4) & (78) & (59) \\ \begin{array}{c}\text { Nickel } \\ \text { (18 cells) }\end{array} & \begin{array}{c}\text { Mean } \\ \text { (std. }\end{array} & 550.6 & 1337 & 472 \\ \text { dev.) } & (10.7) & (39) & (24)\end{array}$

There is some scatter in these data, especially in short circuit current and maximum power, with the scatter being obviously greater in the Motorola process group, but again the data provide no other basis for rhoosing betwcen the two processes. 


\section{BACK SURFACE METALLIZATION}

Work has been concerned primarily with the quality of front surface metallization of solar cells, because metallization of back $\dot{p}+$ surfaces, owing to its much greater area, normally causes fewer problems even when its quality is not very good.

Good back surface metallization has been obtained when using the Motorola process as well as when using electroless nickel alone. We have noted, however, that back surface solder is sometimes obviously rougher, with some gaps, on Motorola process specimens than on specimens plated with nickel only.

This is a subjective judgement, and frequently no distinction is evident, but it appears that, when a difference is obvious, the Motorola process specimens have poorer quality solder coatings on their backs. 
9. CONCLUSIONS

At this point we can state unequivocally that a) the Motorola plating process is an extremely cumbersome and time consuming process, b) its reliability and reproducibility are not as good as the reliability and reproducibility of simple electroless nickel plating, and c) it is compatible with a very limited number of pattern masking techniques.

We also conclude, on the basis of the experiments conducted to date (adhesion measurements, diode data, and illuminated I-V characteristics), that the product of the Motorola process is essentially identical to the product of the single step electroless nickel plating process, with the exception that the Motorola process yields somewhat poorer reproducibility. and demands better control of the phosphorus diffusion process. 
10. RECOMMENDATIONS

Our experience with nickel/solder metallization for low cost solar cells has given us substantial knowledge of the system as well as a recognition of some of its possible shortcomings. This has led us to develop strong opinions concerning appropriate directions for future work, and we include here two specific recommendations for work which we think will prove to be most important.

These recommendations comprise a) a study of different types of electroless nickel plating on silicon with respect to adhesion under thermal stress, and b) the development of electroless chemical deposition of a nickel-copper-nickel metallization of silicon.

10.1 Nickel Metallization and Thermal Stress

We have presented evidence that nickel/solder metalilization on silicon can be produced which has excellent adhesion and which can survive moderate thermal stresses, but it does not perform well under extreme thermal stresses.

We recommend that additional work be done to determine in a more quantitative way the degree of thermal stress that this kind of metallization might reasonably be expected to tolerate. 
Several different techniques are available for producing electroless nickel plates, but only one, using an ammoniacal hypophosphite solution, appears to have received any significant study for silicon solar cell applications. The available techniques use both acidic and alkaline solutions with reducing agents including both phosphorus and boron compounds. The nickel plate itself may contain either phosphorus or boron, and the concentration of the phosphorus or boron appearing in the plate varies with plating conditions.

It is well known that stresses in electroless nickel plates are a sensitive function of the precise compositon of the plates. Therefore we recommend that different kinds of electroless nickel plating be studied with respect to adhesion under conditions of thermal stress.

\subsection{Electroless Nickel-Copper-Nickel Metallization}

The nickel/solder combination provides-the most economical metallization of silicon solar cells whose viability has been demonstrated, but the use of solder presents some important problems.

The cost of solder is the major cost in using the process, varying from $50 \%$ to $80 \%$ of the total metallization process cost, the exact percentage depending on 
precisely how the process is conducted. The relatively large amount of solder which must be used also leads to decreased cell efficiency by shadowing an inordinately large fraction of the cell's surface area, and, in addition, the thick solder makes subsequent panel fabrication processes difficult tó automate in a reliable manner.

It would be most desirable to replace the solder with another metal of lower cost and higher electrical conductivity. Copper is an obvious choice, being relatively inexpensive and having a conductivity approximately the same as that of silver, and an order of magnitude higher than the conductivity of tin/ lead solder.

The use of copper presents two potential problems in solar cell applications, however. Copper diffuses relatively rapidly in silicon, and any copper that enters the silicon might degrade the electrical characteristics of the cell. At the same time, the relatively thin copper layer required for conductivity is subject to serious atmospheric corrosion.

Work done in our laboratories, as well as work reported by others, indicates that a layer of nickel under the copper can adequately shield the silicon from the copper, and it is well known that a coating of nickel can protect copper from corrosion. Thus it appears that a nickel-copper-nickel 
combination offers real potential as metallization for low cost silicon solar cells.

For low cost, high volume processing, the three metal layers must be deposited by electroless chemical reactions. Vacuum deposition processes are costly and wasteful of metal, while electroplating processes would normally require handing of individual cells, another costly procedure.

Electroless plating of copper on nickel and of nickel on copper present some difficulties. Electroless copper plating solutions are notoriously unstable, tending to deposit copper (and cuprous oxide) indiscriminately. Most electroless nickel plating solutions dissolve copper rather than plating nickel on top of the copper. Our own efforts, however, have shown sufficiently encouraging results to lead us to believe that appropriate solutions to these problems exist.

Because electroless plating of nickel-copper-nickel on silicon presents such attractive economic possibilities, and because we are optimistic about overcoming the technical difficulties, we recommend that serious efforts be made to develop a process using electroless deposition of nickelcopper-nickel metallization for low cost silicon solar cells. 
11: WORK STATUS

Work on the first four tasks has been completed. Work on the fifth task is proceeding on schedule.

12. WORK PLAN

Experiments comparing the Motorola process with simple electroless nickel plating will be continued, with emphasis in the next quarter to be placed on thermal stress tests. 
13. REFERENCES

(1) Metallization of Large. Silicon Wafers with PalladiumNickel-Solder Metallization System. Motorola, Inc., Dec. 1978. JPL Contract 954689.

(2) R. A. Pryor, DOE/JPI Contract 954689, Final Report, 1978, Motorola, Inc.

(3) A. Brenner and G. Riddell, J. Res. N. B. S., 37, 32 (1946); Proc. Am. Electroplat. Soc., 33, 23 (1946).

(4) F. A. Lowenheim, ed., "Modern Electroplating," 3rd ed., John Wiley \& Sons, Inc., New York, N.Y. $(1974)$.

(5) R. C. Petersen, DOE/JPL Contract No. 954854, Sixth Quarterly Report, April, 1980, Solarex Corporation. 
APPENDIX A

MOTOROLA PROCESS

\section{A. INTRODUCTION}

In pursuance of JPL Contract No. 954689; an advanced process for silicon solar cell metallization has been developed and demonstrated to be capable of permitting high reliability, large volume, and low cost. This metallization process, which has been demonstrated on a developmental laboratory scale, is specified in this document.

This process is the forerunner of a production-ready process and requires advanced development in order to be entirely suitable for the high through-put, low cost technology required for long term goals. For example, chemical . plating solutions are now contained and used in small volume beakers rather than in large volume, continuously replenished tanks. Heat treatments are performed in quartz tube lined resistance heated furnaces rather than using a more appropriate belt furnace. The fundamental process has, however, been defined.

The process specified here is relatively complex and is considered to contain the maximum number of process steps required for assured metallization of $n$-on-p solar cells with $n+$ front surfaces and p+ back surfaces. It is possible that, in the future, this process may be altered or eliminated. To 
date, attempts to shorten the process have met with varying degrees of success. Such attempts have been sufficiently successful to show feasibility, but not successful enough to guarantee a favorable outcome each and every time. This guarantee must be a prerequisite for a process sequence recommendation.

The process sequence recommended here may require minor modifications to account for different types of solar cell substrates and to account for the previous processing history of substrates prior to metallization. For example, while the initial rinse in a dilute hydrofluoric acid solution, as recommended here, is sufficient cleaning for most types of samples, some samples prepared in different fashion may require a more elaborate clean to ensure adequate plating to the silicon surface. The process does, however, assure a high quality metallization and cell performance on standard Motorola solar cells. Specific times, temperatures, weights and volumes have been given in the process specification. Unless otherwise stated, it has been found that minor variations in these quantities have little impact on process performance, thus ensuring that adequate process control will be feasible.

The metallization scheme is comprised of three layers. Palladium, through the formation of palladium silicide at elevated temperatures, forms the ohmic contact to the silicon surface. Palladium is deposited first with an immersion 
palladium solution to a thickness near $50 \AA$. Palladium thickness is increased with an electroless palladium plating solution to about $1000 \AA$. Nickel; plated on top of the palladium silicide/palladium layer to a thickness of about $5000 \AA$, forms a solderable interface. Lead-tin solder provides electrical conductivity and is applied by means of a dip in molten solder. 


\section{B. MATERIALS AND SUPPLY LIST}

Wet Chemicals

Acetone

Ammonium fluoride, $40 \% \mathrm{NH}_{4} \mathrm{~F}$, semiconductor grade

Ammonium hydroxide $\left(\mathrm{NH}_{4} \mathrm{OH}\right), 28 \% \mathrm{NH}_{3}$, semiconductor grade

Chlorothene V.G.

Deionized water (DI $\left.\mathrm{H}_{2} \mathrm{O}\right), 14$ megohm-cm purity

Hydrochloric acid, $37 \% \mathrm{HCl}$, semiconductor grade

Hydrofluoric acid, $498 \mathrm{HF}$, semiconductor grade

Nitric acid, $70 \% \mathrm{NHO}_{3}$, semiconductor grade

Peanut oil

Solder flux, type RA, Kester No. 1544

\section{Dry Chemicals}

Ammonium chloride, $\mathrm{NH}_{4} \mathrm{Cl}$, reagent grade

Nickel chloride, $\mathrm{NiCl}_{2} \cdot 6 \cdot \mathrm{H}_{2} \mathrm{O}$, reagent grade

Palladium chloride, $\mathrm{PdCl}_{2}$

Sodium citrate, $\mathrm{Na}_{3} \mathrm{C}_{6} \mathrm{H}_{5} \mathrm{O}_{7} \cdot 2 \mathrm{H}_{2} \mathrm{O}$, reagent grade

Sodium hypophosphite, $\mathrm{NaH}_{2} \mathrm{PO}_{2} \cdot \mathrm{H}_{2} \mathrm{O}$, reagent grade

Tin-Lead solder, Kester $60 \mathrm{Sn}-40 \mathrm{~Pb}$ 


\section{CHEMICAL SOLUTION PREPARATION}

CAUTION: Chemcial exhaust hoods are required for safe preparation and use of chemical solutions.

\section{Dilute Hydrofluoric Acid $\left(50: 1 \quad \mathrm{H}_{2} \mathrm{O}: \mathrm{HF}\right)$}

For approximately 3 liters of dilute HF solution add $60 \mathrm{ml} \mathrm{HF}$ to $3000 \mathrm{ml}$ deionized water (DI $\mathrm{H}_{2} \mathrm{O}$ ). Stir to mix thoroughly. For use during processing solar cells, a 41 teflon beaker is a convenient container. The container should be covered when not in use.

\section{Immersion Palladium}

The palladium chloride is most readily entered into solution when the solution temperature is elevated. Mixing is most easily accomplished using a Pyrex beaker $\left(\begin{array}{ll}4 & 1\end{array}\right)$ on a hot plate with a magnetic stirrer.
a) Heat $3000 \mathrm{ml}$ of $\mathrm{DI} \mathrm{H}_{2} \mathrm{O}$ to approximately $40^{\circ} \mathrm{C}$.
b) Add $9 \mathrm{ml}$ of hydrochloric acid and $\mathrm{mix}$.
c) Add $0.08 \mathrm{~g}$ of palladium chloride and dissolve thoroughly.
d) Add $200 \mathrm{ml}$ of ammonium fluoride and stir until clear. Allow this solution to stand a minimum of 4 hours before use and allow to cool to room temperature.

\section{Aqua Regia (metal etch solution)}

For 4 liters of aqua regia add 1 l of nitric acid to 31 of hydrochloric acid mix thoroughly. Allow to stand until 
activated as indicated by evolution of bubbles within the solution.

Palladium Stock Solution

Because palladium chloride is somewhat difficult to dissolve, it is convenient to prepare a concentrated stock solution which is diluted for use in electroless palladium bath. A beaker of at least 21 capacity and a hotplate with a magnetic stirrer are convenient.
a) Heat $950 \mathrm{ml}$ of $\mathrm{DI} \mathrm{H}_{2} \mathrm{O}$ to approximately $40^{\circ} \mathrm{C}$.
b) Add $50 \mathrm{ml}$ of hydrochloric acid and mix thoroughly.
c) Add $25 \mathrm{~g}$ of palladium chloride and stir until completely dissolved. This may require as long as 4 hours.

Electroless Palladium

This formula is for approximately 41 of electroless palladium solution. A quartz or Pyrex beaker of about 71 capacity is a convenient container and a hot plate with a magnetic stirrer is useful.

a) Add $320 \mathrm{ml}$ of palladium stock solution to $640 \mathrm{ml}$ of ammonium hydroxide. Allow to stand a minimum of 2 hours. It is recommended that the solution be stored overnight in a high density polyethelene bottle, or the equivalent.

b) Filter the solution, add to $3000 \mathrm{ml}$ of $\mathrm{DI} \mathrm{H}_{2} \mathrm{O}$ and mix thoroughly. 
c) Add $108 \mathrm{~g}$ of ammonium chloride and mix.

c) Add $15 \mathrm{~g}$ of sodium hypophosphite and mix. Heat solution to $50^{\circ} \mathrm{C}$ for use and keep beaker covered to reduce evaporation. Maintain a $\mathrm{pH}$ near 9.7 by addition of ammonium hydroxide as needed.

\section{Electroless Nickel}

This formula is for approximately 41 of electroless nickel solution. A quartz or Pyrex beaker of about 71 capacity is a convenient container and a hot plate with a magnetic stirrer is useful.

a) Add $120 \mathrm{~g}$ of nickel chloride to $3500 \mathrm{ml}$ of $\mathrm{DI} \mathrm{H}_{2} \mathrm{O}$ and $\operatorname{mix}$ thoroughly.

b) Add $200 \mathrm{~g}$ of ammonium chloride and mix.

c) Add $336 \mathrm{~g}$ of sodium oitrate and mix.

c) Add $40 \mathrm{~g}$ of sodium hypophosphite and mix.

d) Add $500 \mathrm{ml}$ of ammonium hydroxide.

Heat solution $80^{\circ} \mathrm{C}$ for use and keep beaker covered to reduce evaporation. Maintain a pH near 10 by addition of ammonium hydroxide as needed. 


\section{EQUIPMENT AND FACILITIES}

a. CAUTION! Chemical exhaust hoods are required for safe preparation and use of acid solutions and plating solutions :

Either standard exhaust hoods or laminar flow exhaust hoods are suitable for mixing solutions and plating solar cells. Hoods should be equipped with running $\mathrm{DI} \mathrm{H}_{2} \mathrm{O}$, acid drains, suitable work space, and temperature controlled, stirring hotplates. This, of course, assumes that this solar cell metallization process is to be practiced on a laboratory scale. Full production scale would necessitate a larger scale facility than beakers and hotplates.

b. For heat treatments a resistance heated, quartz lined furance tube, such as table-top style Thermco Mini-Brute, is recommended. Again, for large production it may be much more suitable to use a beit furnace arrangement.

c. Circular or square solar cell substrates can be dried (following plating and rinsing operations) satisfactorily by centrifigal spin dryers, such as the Fluoroware Model Kl00.

d. Circular solar cell substrates can be conveniently handled in batches of up to 25 cells by using standard teflon wafer carriers for wet chemistry steps and standard quartz boats for heat treatments. These teflon carriers and quartz boats are 
compatible so that wafers may be dump.transfered from one to the other.

e. In promoting good plating reactions at the silicon surface in the immersion palladium solution, it has been found that high ambient light levels are desirable. To achieve this, a high intensity lamp, such as the quartz-halogen projector lamp type ENH, is mounted approximately two feet above the beaker containing the immersion palladium solution.

f. Soldering of individual cells can be accomplished with a soldering system as simple as an ordinary solder pot which merely melts and contains the solder and controls the molten solder temperature. The dimensions of the pot must be large enough to permit vertical entry of a solar cell.

Equipment List

Teflon, Pyrex, or Quartz Beakers and Lids

Teflon Wafer Carriers

Water Rinse Tanks

Wafer Spin Dryer

Thermometers

Hi-Intensity Lamp, 120V, 250 Watts

Timers

Teflon Stirring Rods 
Equipment List (con't)

Hot Plates, equipped with magnetic stirrers and temperature controls

Nalgene Storage Bottles -- $1000 \mathrm{ml}$ and $1 \mathrm{gal}$.

Teflon Tipped Tongs

Teflon Tweezers

Exhausted hood with acid and solvent drains and running $\mathrm{DI} \mathrm{H}_{2} \mathrm{O}$

Protective Gloves

Protective Clothing

Funnels

Polypro Graduated Beakers

Graduated Cylinders

Solder Dip Station

Sintering Furnace, Quartz lined, with $\mathrm{N}_{2}$ flow

Quartz Furnace Wafer Carriers 


\section{E. PROCESS SEQUENCE AND PROCEDURES}

Step 1. Immersion Palladium Coat

1.1 Load cells into teflon carrier.

1.2 Place loaded carrier into 50:1 $\mathrm{H}_{2} \mathrm{O}: \mathrm{HF}$ solution for $30 \mathrm{sec}$. Use gentle agitation.

1.3 Directly from 50:1, place carrier into immersion palladium solution.

1.4 Turn on high intensity light over immersion palladium solution. Agitate carrier continuously for $3 \mathrm{~min}$.

1.5 Rinse carrier and cells for $5 \mathrm{~min}$. in running $\mathrm{DI} \mathrm{H}_{2} \mathrm{O}$.

1.6 Place carrier and cells into aqua regia for $5 \mathrm{sec}$.

1.7 Rinse wafers for $15 \mathrm{~min}$. in running $\mathrm{DI} \mathrm{H}_{2} \mathrm{O}$.

1.8 Place carrier into 50:1 solution for $20 \mathrm{sec}$. Use gentle agitation.

1.9 Directly from 50:1, place carrier into immersion palladium solution illuminated by high intensity light for 5 min. with continuous agitation.

1.10 Rinse carrier and cells for 5 min. in running $\mathrm{DI} \mathrm{H}_{2} \mathrm{O}$ and spin dry.

1.11 After drying, inspect cells for immersion palladium coverage. Plated silicon surface appearance should be hazy with a light tan color.

\section{Step 2. Heat Treatment}

2.1 Dump transfer cells from teflon carrier to quartz boat for furnace. 
2.2 Place boat into center of furnace hot zone at $300^{\circ} \mathrm{C}$ for $15 \mathrm{~min}$. Use a continuous nitrogen purge and an end cap on the quartz tube.

2.3 Remove boat with cells and allow to cool.

2.4 Dump transfer cells back into teflon carrier.

Step 3. Electroless Palladium Plate

3.1 Immerse carrier of cells into $50: 1$ solution for $20 \mathrm{sec}$. with agitation.

3.2 Directly from 50:1 solution, place carrier into immersion palladium solution illuminated by high intensity light for $2 \mathrm{~min}$. with continuous agitation.

3.3 Rinse in running $\mathrm{DI} \mathrm{H}_{2} \mathrm{O}$ for $2 \mathrm{~min}$.

3.4 Place carrier of cells into electroless palladium solution for $45 \mathrm{sec}$. using gentle agitation. Solution temperature should be $50^{\circ} \mathrm{C}$ and ambient light level should be very low.

3.5 Rinse cells for $10 \mathrm{~min}$. in running $\mathrm{DI} \mathrm{H}_{2} \mathrm{O}$ and spin dry. 3.6 After drying, inspect cells for electroless palladium coverage. Plated silicon surface should have a bright metallic finish with a warm, gold coloration.

Step 4. Heat Treatment

4.1 Dump transfer cells from telfon carrier to quartz boat for furnace.

4.2 Place boat into center of furnace hot zone at $300^{\circ} \mathrm{C}$ for $30 \mathrm{~min}$. Use a continuous nitrogen purge and an end cap on the quartz tube. 
4.3 Remove boat with cells and allow to cool.

4.4 Dump transfer cells back into teflon carrier.

Step 5. Electroless Nickel Plate

5.1 Immerse carrier of cells into electroless nickel solution for $5 \mathrm{~min}$. using gentle agitation. Solution temperature should be $80^{\circ} \mathrm{C}$.

5.2 Rinse cells for 10 min. in running $\mathrm{DI} \mathrm{H}_{2} \mathrm{O}$ and spin dry.

5.3 After drying, inspect cells for electroless nickel coverage: Plating should have very bright, metallic appearance.

Step 6. Solder

In the process described in this step, each cell is individually solder coated and given an initial solvent rinse. When a teflon carrier full of cells (one batch) is accumulated, all cells are yiven a final rinse and dry.

6.1 Load cell into teflon tipped soldering tongs.

6.2 Using tongs, immerse cell into soldering flux, then allow excess flux to drain.

6.3 Using tongs, immerse cell into solder pot at $240^{\circ} \mathrm{C}$ for approximately 1 sec. The surfare of the solder pot is covered with peanut oil to prevent dross formation on the molten solder surface.

6.4 Allow cell to cool and solder to solidify in horizontal position. 
6.5 Immerse cell into a beaker of chlorothene and agitate to remove most flux residue and oil.

6.6 Place cell into teflon carrier which is immersed in a second beaker of chlorothene. Let stand until carrier is full or each cell in lot has been soldered.

6.7 When carrier is full or soldering is complete, agitate carrier in chlorothene then place in beaker of acetone. Let stand for $5 \mathrm{~min}$.

6.8 Rinse cells in running $\mathrm{DI} \mathrm{H}_{2} \mathrm{O}$ and spin dry. 